\title{
Value Added and Profitability Analysis of Bamboo Products in Case of Banja District Awi Zone Amhara Regional State Ethiopia
}

Mulat Mengistu ( $\square$ mulatmengistu122@gmail.com )

Debre markos university https://orcid.org/0000-0002-8589-3658

\section{Asmamaw Alemu}

University of Gondar

Abebe Dagnew

university of Gondar

\section{Research}

Keywords: bamboo, profitability, value added

Posted Date: December 11th, 2020

DOI: https://doi.org/10.21203/rs.3.rs-125111/v1

License: (c) (i) This work is licensed under a Creative Commons Attribution 4.0 International License.

Read Full License 


\section{Abstract}

\section{Background}

Bamboo meets a rising and diverse consumer demands and generates income and contribute to reforestation and climate change mitigation due to its rapid growth and environmentally friendly character. Most bamboo processing enterprises and farmer and consumers use manual technology and produce less durable products. Since there is no research conducted in the area related to profitability of different bamboo products and the distribution of value added Therefore, this study aims to analyse the profitability of bamboo products for producers, traders and processors in the same way it analyses the value added distribution among different agents.

Methods

To collect primary data 122 smallholder bamboo producers, 13 traders and 16 bamboo product processors were selected. To analyse the data descriptive statistics were employed.

Results

On average producers supply 374.79 bamboo culms and earn revenue of $7,623.23$ ETB. The total value added at the producer level was 15.64 ETB per culm. On average local traders, retailers and wholesalers earn $7.52 \%, 9.51 \%$ and $9.23 \%$ of profit Margin and these traders earn average revenue of $66,420 \mathrm{ETB}$, 129,360ETB and 280,343 ETB respectively. Traditional bamboo product processors produce 687 traditional bamboo chairs on average per year and gained 3.06 ETB/culm as a net profit. Bamboo furniture enterprises on average process 823 modern bamboo chair per year and they earn 197.91 ETB per chair as a net profit. Higher value is added at bamboo furniture enterprise level and lower value is added at producer and trader level.

\section{Conclusion}

The result of the study revealed that all actors have positive profit and value is added by different chain actors and distributed to different agents. Bamboo furniture enterprises gained higher profit margin than traditional bamboo processors. The contribution of the bamboo sector to the government economy is limited. Based on the finding of the study, an effort should be made to increase the contribution of the sector to the national economy. In addition to this, providing working capital and working place and enhancing the processors' skill and capacity to transform the business into more modern and profitable bamboo furniture enterprise is advisable.

\section{Background}

Bamboo is one of the most important vegetation resources in highlands of Ethiopia with diverse local and national importance intermes of filling subsistence needs and cash income (Godfrey, 2014). Bamboo meets a rising and diverse consumer demands and generates income and contribute to reforestation and 
climate change mitigation due to its rapid growth and environmentally friendly character (Pabuayon, 2009; Lobovikov et al, 2011). Yushania alpina is found in different parts of Ethiopia. It covers a large area between Bale Mountain, Bonga and Metu in South West part of Ethiopia and up to Dangla in the North. It covers $20 \%$ of Ethiopia's total bamboo area (Getachew and Wubalem, 2014).

The markets for bamboo are not well developed (Zenebe, 2014). The majority of output is used for subsistence while only a third of the estimated production is delivered for the market and there is weak linkage among intermediaries and trade is highly restricted to local and national markets (Endalamaw and Pretzsch, 2012).

In Awi zone and the Amhara National Regional State, bamboo is an integral part of the day to day life of many households and it is source of income for many farmers and urban inhabitants engaged in offfarm activities (BoA, 2012). Banja is one of the district in Awi zone which has suitable agro ecology to produce different crops and plants. The district is endowed by highland bamboo resource and it is the main source of income. Most bamboo processing enterprises and farmer and consumers use manual technology and produce less durable products (Endalamaw et al, 2013).Since there is no research conducted in the area related to profitability of different bamboo products and the distribution of value added in the form of profit (producers, traders and processors), remuneration (labour) and government revenue(tax and levies). Therefore, this study aims to analyse the profitability of bamboo products for producers, traders and processors in the same way it analyses the value added distribution among different agents.

\section{Research Methodology}

\section{Description of the study area}

This study was conducted in Banja District Awi Zone Amhara regional State, Ethiopia. It is bordered on the south by Ankesha, on the West by Guangua, on the North by Fagita Lekoma and in the East by the West Gojjam zone. The district is composed of 26 kebeles out of this 25 are rural kebeles and one urban kebele. Out of the 25 rural kebele 20 kebeles produce the highland bamboo. Injibara town is the capital of Banja district. It is located about $442 \mathrm{kms}$ North West to Addis Ababa and $116 \mathrm{kms}$ south of Bahir Dar (BWADO, 2006). Banja district was selected as an entry point due to bamboo resource production, distribution, processing and marketing of bamboo and its products and based on its significance contribution to the community specifically and the country in general.

Total population of the district was estimated at 121,511 . Out of this $60,354(49.67 \%)$ were male and $61,157(50.33 \%)$ were female (CSA, 2007). The total area coverage of the district is $47915.82 \mathrm{ha}$. The current land use pattern includes 12,277 ha cultivated land, 21,141.57 ha grazing/pasture land, 14,188.87 ha covered by forest from which $65.65 \%$ covered by plantation forest and the remaining area covered by natural forest. Mixed farming system is practiced in the area with rain fed crop production and animal raring being the main source of livelihoods (BWADO, 2006). 


\section{Sampling Technique and Sample Size Determination}

Two stage sampling technique was used to draw the sample. In the first stage, with the consultation of agricultural and development agents of the district, bamboo producer kebeles were identified and four producer kebele were selected randomly from 20 bamboo producer kebeles. The sampled kebele include Kessa Chewusa, Gashena Akayta, ledeta and Surta.

In the second stage, from each sampled kebele bamboo producer farmers were listed out with the help of development agents at kebele level. From these population lists, 122sample farmers were selected randomly based on probability proportional sampling to size (Table 1).

The sample size is determined by using Yamane (1967) formula. In the district 6690 farmers produce highland bamboo and in the sampled kebele 1449 farmers produce highland Bamboo.

$$
\mathrm{n}=\frac{\mathrm{N}}{1+\mathrm{N}(\mathrm{e})^{2}}
$$

Where, $\mathrm{N}$ is population of the district bamboo producer

$\mathrm{n}$ is the sample size

e is the level of precision which is $9 \%$

$$
\mathrm{n}=\frac{\mathrm{N}}{1+\mathrm{N}(\mathrm{e})^{2}}=\frac{6690}{1+6690(0.09)^{2}}=122 \mathrm{HHS}
$$

\begin{tabular}{|lllll|}
\hline Name of kebele & Number of producer & Proportion & Sample size & Sampling intensity \\
\hline Kessa Chewusa & 492 & 0.34 & 42 & 8.5 \\
\hline Gashena Akayta & 350 & 0.24 & 29 & 8.29 \\
\hline Ledeta & 325 & 0.22 & 27 & 8.31 \\
\hline Surta & 282 & 0.2 & 24 & 8.51 \\
\hline Total & 1449 & 1 & 122 & 8.42 \\
\hline
\end{tabular}

Thirteen Traders ( 3 wholesalers, 5 retailers and 5 local traders) were selected by using snowball sampling. Six processors ( 1 furniture enterprise and 5 traditional product processors) from Kessa were selected purposively because processors are located at Kessa and Injibara town in the road side and in Injibara town there are two licensed bamboo processing enterprises, one is in the form of cooperative enterprise and the other one is private owned enterprise. Therefore, due to small number of these enterprises both of them were included in the sample. In addition to the licensed enterprises, there are a number of unlicensed traditional bamboo processors at Injibara town in the road side. Therefore, by using 


\section{Data type, Sources and Method of Data Collection}

Quantitative and qualitative data were collected from primary and secondary data source to deal with objectives. Primary were collected through semi-structured interview schedule by using open ended and close ended questions, field observation. Secondary data were collected from Local level trade offices', office of agriculture, annual reports, published and unpublished documents and internet sources were reviewed to support the primary data.

\section{Method of data analysis}

Descriptive statistics includes mean, percentage; frequency and standard deviation were used in the process of examining socio-economic and demographic characteristics of sampled respondents, profitability, value added and its distribution among different agents.

\section{Results And Discussion}

\section{Demographic and socio economic characteristics of highland bamboo traders}

Highland bamboo trade is male dominated business that all of the traders are male headed. It indicates that in bamboo trading activity the participation of women is very limited due to different barriers like working culture of the community. The education level of the trader varies from the informal education to completion of secondary school. The proportion of education level is as follows; $7.7 \%$ of the trader cannot read and write, $61.5 \%$ of the traders can read and write without attending formal education, $15.4 \%$ attend primary school and $15.4 \%$ of the sampled traders have attended high school education. Bamboo traders have a mean experience of 10.08 with a standard deviation of 5.074 years. In the study area wholesalers, retailers and local collectors were involved. There are different barrier of entry to bamboo trading activity such as issues related to trade license and existence of unlicensed bamboo traders in the area. The livelihood of traders depends on the farming activity and trading of bamboo and related products (Table 2).

Table 2: Demographic and socio economic characteristics of sampled traders 


\begin{tabular}{|llll|}
\hline Categorical variables & Item & Frequency & Percent \\
\hline Sex & Male & 13 & 100 \\
\hline Marital status & Female & 0 & 0 \\
& Married & 13 & 100 \\
\hline Education status & Cannot read and write & 1 & 7.7 \\
\hline & Can read and write & 8 & 61.5 \\
\cline { 2 - 4 } & Attend primary school & 2 & 15.4 \\
\cline { 2 - 4 } & Attend secondary school & 2 & 15.4 \\
\hline Continuous variables & Min max & Mean & SD \\
\hline Experience & 420 & 10.08 & 5.074 \\
\hline
\end{tabular}

Source: Field survey result, 2020

\section{Demographic and socio economic characteristics of bamboo processors}

As shown in the table below all of the bamboo processors were male headed and $15.4 \%$ of the processor were married. It indicates that in the bamboo processing mostly the young people especially the students were involved in this activity. In the study area some females participate on the production of bamboo mat near to the main road of the city. The education level result showed that $46 \%$ of the processors have attended secondary school and $30.8 \%$ of the processors have attended the primary school education. This indicates that the bamboo processing activity is a good source of job opportunity and it needs educated people. The sampled bamboo processors have a mean working experience of 6.62 years with a variation of 3.84 year among them. Bamboo processing is used as a means of livelihood for bamboo processors.

Table 3: Demographic and socio economic characteristics of bamboo processor 


\begin{tabular}{|llll|}
\hline Categorical variable & Item & Frequency & Percent \\
\hline Sex & Male & 13 & 100 \\
\hline Marital status & Single & 11 & 84.6 \\
\hline Education status & Married & 2 & 15.4 \\
& Can read and write & 1 & 7.7 \\
\hline & Attend primary school & 4 & 30.8 \\
\hline & Attend secondary school & 6 & 46.2 \\
\hline Continuous variable & Min max & 2 & 15.4 \\
\hline Experience & 215 & Mean & SD \\
\hline
\end{tabular}

Source: Field survey result, 2020

\section{Profitability analysis of bamboo products}

\section{Profitability analysis of bamboo culm at producers level}

Bamboo producers have used family labour and own land for bamboo production. Therefore, in the profitability analysis the opportunity cost of labour and rent for own land were considered and the market price to purchase inputs were used. On average producers allocate 0.15 ha of land for bamboo plantation and the average number of bamboo culm supplied by producer was $374.97 \mathrm{bamboo}$ culm.

The average production cost per bamboo culm is 8.41 ETB. Bamboo producers did not incur monetary cost rather opportunity cost of family labour and rent for land were considered. These constitute $31.98 \%$ rent for land and $46.24 \%$ opportunity costs of labour. On average producers supply 374.79 bamboo culms and earn revenue of 7,623.23 ETB. By deducting all the production and marketing costs from the total revenue producers earn 4475.71 ETB which makes $58.71 \%$ of profit margin (Table 4). Tefera et al. (2013) found that producers earn $90.89 \%$ of profit margin. The present study indicates that the profit of producers become decrease through time. The total value added at the producer level was 15.64 ETB per culm. It is the summation of profit, remuneration (labour) and government revenue but at the producer level bamboo producers did not pay tax for the government.

Table 4: Bamboo producer costs, profit margin and value added 


\begin{tabular}{|c|c|c|c|}
\hline Cost items & $\begin{array}{l}\text { Birr per } 374.97 \text { culm/ } 0.15 \\
\text { ha }\end{array}$ & $\begin{array}{l}\text { Cost per } \\
\text { culm(ETB) }\end{array}$ & $\begin{array}{l}\text { Production cost } \\
\text { (\%) }\end{array}$ \\
\hline Site preparation & 290.37 & 0.77 & 9.47 \\
\hline Planting labor & 201.13 & 0.54 & 6.64 \\
\hline Weeding cost & 114.81 & 0.31 & 3.81 \\
\hline Fencing material cost & 194.75 & 0.52 & 6.4 \\
\hline Fencing labor cost & 213.61 & 0.57 & 7.01 \\
\hline Culm cutting cost & 294.98 & 0.79 & 9.72 \\
\hline Culm harvesting cost & 291.6 & 0.78 & 9.59 \\
\hline Rent for land & 973.81 & 2.6 & 31.98 \\
\hline Material cost & 100 & 0.27 & \\
\hline Total production $\operatorname{cost}(\mathrm{A})$ & 2675.06 & 7.15 & 84.62 \\
\hline Marketing cost(B) & 472.46 & 1.26 & 15.38 \\
\hline \multicolumn{4}{|l|}{ Transportation cost } \\
\hline Overall cost $(A+B)=C$ & 3147.52 & 8.41 & 100 \\
\hline $\begin{array}{l}\text { Average selling price per } \\
\text { culm }\end{array}$ & 20.34 & & \\
\hline Total revenue $(p * Q)=D$ & 7623.23 & 20.34 & \\
\hline Net return/profit (D-C) & 4479.37 & 11.93 & \\
\hline Profit margin & $58.73 \%$ & & \\
\hline Value added & 5885.87 & 15.69 & \\
\hline
\end{tabular}

Source: Field survey result, 2020

\section{Profitability analysis of bamboo culm at traders' level}

On average local traders, retailers and wholesalers earn $7.52 \%, 9.51 \%$ and $9.23 \%$ of profit

Margin and these traders earn average revenue of 66,420 ETB, 129,360ETB and 280,343 ETB respectively. These low profit margins discourage the traders to engage in bamboo trading business. From these traders, wholesalers incur the highest marketing cost since these traders purchase large number of bamboo culm than other traders. The value added at local trader, retail level and wholesale level was 2.81 ETB, 4.84 ETB and 3.77ETB respectively (Table 5). Tefera et al. (2013) reported that traders earn 32.78\% of the profit margin 
Table 5: Profitability analysis of bamboo culm traders

\begin{tabular}{|lllllll|}
\hline & \multicolumn{2}{l}{ Local traders } & Retailers & \multicolumn{3}{l|}{ Wholesalers } \\
\hline Cost items and price & Total & Birr/Culm & Total & Birr/culm & Total & Birr/culm \\
\hline Average Culm handled & 2460 & & 4200 & & 9667 & \\
\hline purchasing price & 55,104 & 22.4 & 103,320 & 24.6 & 225,531 & 23.33 \\
\hline Transportation cost & 3260 & 1.33 & 4000 & 0.95 & 14000 & 1.45 \\
\hline Telephone cost & 1120 & 0.46 & 1730 & 0.41 & 4333.33 & 0.45 \\
\hline Loading and unloading & 1940 & 0.79 & 4675 & 1.11 & 9866.67 & 1.02 \\
\hline Tax & 0.00 & 0.00 & 2880 & 0.69 & 4000 & 0.41 \\
\hline Levy & 0.00 & 0.00 & 460 & 0.12 & 766.67 & 0.08 \\
\hline Total marketing costs & 6320 & 2.58 & 13745 & 3.28 & 32966.67 & 3.41 \\
\hline Total cost & 61424 & 24.98 & 117065 & 27.88 & 254497.67 & 26.74 \\
\hline Average selling price & - & 27 & - & 30.8 & - & 29 \\
\hline Gross revenue & 66420 & & 129360 & & 280343 & \\
\hline Net profit & 4996 & 2.02 & 12295 & 2.92 & 25845.33 & 2.26 \\
\hline Profit margin (\%) & 7.52 & & 9.51 & & 9.23 & \\
\hline Value added & 6936 & 2.81 & 20,310 & 4.84 & 40478.67 & 3.77 \\
\hline
\end{tabular}

Source: Field survey result, 2020

\section{Profitability analysis of bamboo processors}

Traditional bamboo product processors produce 687 traditional bamboo chairs on average per year. To produce a single three setter bamboo chair on average two bamboo culm is required. The cost of processing constitutes $64.42 \%$ purchasing price for bamboo culm, $34.7 \%$ opportunity cost for labor, $0.62 \%$ cost for drill and cost for brush constitutes $0.26 \%$ of the total production cost. Annually bamboo processors earn 4,211.31ETB by selling 687 three setter bamboo chair. As indicated in Table 6 processors gained 3.06 ETB per culm as a net profit .It indicates that the profit is not balanced with the processing activity. In the study area all of the traditional bamboo chair producers produce the bamboo products manually. It needs attention to transform these processors into better business work. Solomon et al. (2016) indicated that bamboo processors gained 10.95 ETB per culm. The author stated that the cost benefit analyses in the existing market chain processors were highly beneficial. But in this study it did not encourage the processor to engage in bamboo processing business. 
Table 6: Profitability analysis of bamboo processors

\begin{tabular}{|llll|}
\hline Cost item & Cost(ETB)/chair & Cost/culm & Percent \\
\hline Purchasing price & 47.84 & 23.93 & 64.42 \\
\hline Labor cost (opportunity cost) & 25.77 & 12.89 & 34.70 \\
\hline Drill cost & 0.46 & 0.23 & 0.62 \\
\hline Brush & 0.19 & 0.095 & 0.26 \\
\hline Total processing cost $(\mathrm{A})$ & 74.26 & 37.15 & 100 \\
\hline Selling price(B) & 80.39 & 40.2 & \\
\hline Gross revenue( $\left.\mathrm{p}^{\star} \mathrm{Q}\right)$ & 55227.97 & - & \\
\hline Profit (B-A) & 6.13 & 3.06 & \\
\hline Profit margin $(\%)$ & $7.62 \%$ & $7.62 \%$ & \\
\hline Value added & 31.9 & 15.95 & \\
\hline
\end{tabular}

Source: Field survey data, 2020

\section{Profitability analysis of bamboo furniture enterprises}

Bamboo furniture enterprises on average process 823 modern bamboo chair per year. All bamboo furniture enterprises used on average two bamboo culm to make a single modern bamboo chair. Bamboo furniture enterprises earn highest annual income than other actors. These enterprises produce better value added products than the traditional bamboo product producers. On average the bamboo furniture enterprises earn 197.91 ETB per chair. The cost for culm and labour cost constitutes $26.25 \%$ and $20.67 \%$ of the total processing cost. The profitability analysis at bamboo furniture enterprise level indicates that the enterprises gained 197.91ETB per chair .It indicates that investing on modern bamboo processing business leads to better business profit. Dafroza (2016) reported that processors received $46 \%$ of the profit margin.

Table 7: Costs, profit margin and value added at bamboo furniture enterprise level 


\begin{tabular}{|llll|}
\hline Cost item & Cost (ETB)/chair & \multicolumn{2}{l|}{ Cost per culm percent } \\
\hline Culm purchasing price & 48.67 & 24.34 & 26.25 \\
\hline Electricity and house rent & 7.48 & 3.74 & 4.03 \\
\hline Labor cost & 38.33 & 19.17 & 20.67 \\
\hline Tax & 3.77 & 1.89 & 2.03 \\
\hline Varnish & 29.5 & 14.75 & 15.91 \\
\hline Glue & 10.67 & 5.34 & 5.76 \\
\hline Nail & 24 & 12 & 12.94 \\
\hline Cost for coloring & 23 & 11.5 & 12.4 \\
\hline Total cost(A) & 185.42 & 92.71 & 100 \\
\hline Selling price(B) & 383.33 & 191.67 & \\
Gross revenue $\left(\mathrm{p}^{\star} \mathrm{Q}\right)$ & $315,480.59$ & - & \\
\hline Profit(B-A) & 197.91 & 98.96 & \\
Profit margin $(\%)$ & 51.63 & $51.63 \%$ & \\
Value added & 240.01 & 120.01 & \\
\hline
\end{tabular}

Source: Field survey data, 2020

\section{Value Added and its Appropriation}

Value added can be distribute into the different node of the value chain as net profit, personal remuneration and taxes (Vedeld et al.,2004). Value added is not only an element of income for the enterprises but also it includes the value added distribution along the fundamental agents of the national economy: households(recipients of the return to labour, financial institutions (interest charges), government adminstration(taxes) and enterprises(gross or net profit).

The total value added in the bamboo product was estimated about 163.02 ETB per a single bamboo culm. It was distributed along the agents .About $9.59 \%$ of the total value added was shared by bamboo producers. loca traders,retailers and wholesalers account $1.72 \%, 2.97 \%$ and $2.31 \%$ of the total value added respectively. Traditional bamboo product processors and bamboo furniture enterprises account $9.78 \%$ and $73.62 \%$ of the total value added. It indicates that bamboo furniture enterprises share the highest portion of the total value added.

Table 8: Value added at different stages 


\begin{tabular}{|lll|}
\hline Value added stage & ETB per culm & Percent \\
\hline Producers & 15.64 & 9.59 \\
\hline Local traders & 2.81 & 1.72 \\
\hline Retailers & 4.84 & 2.97 \\
\hline Wholesalers & 3.77 & 2.31 \\
\hline Bamboo processor & 15.95 & 9.78 \\
\hline Bamboo furniture enterprises & 120.01 & 73.62 \\
\hline Total & $\mathbf{1 6 3 . 0 2}$ & 100 \\
\hline
\end{tabular}

Source: extracted from the above table

The total value added is appropriated to different agents as personal remuneration for labour, profit for the enterprises and taxes and levies for government administration. Majority of the total value added (74.84 \%) is appropriated as net profit for producers, traders and processors and the remaining $23.76 \%$ and $1.96 \%$ of the total value added was accounted for labour in the form of remuneration and government administration in the form of taxes and levies respectively. It indicates that the income generation and employment creation at different stages and the rise of government in bamboo value chain (Figure 1)

\section{Conclusion And Recommendation}

The result of the study revealed that all actors have positive profit and value is added by different chain actors and distributed to different agents. The total production cost is 3147.52 ETB. On average producers supply 374.79 bamboo culms and earn revenue of 7,623.23 ETB. By deducting all the production and marketing costs from the total revenue producers earn 4475.71 ETB which makes $58.71 \%$ of profit margin. On average local traders, retailers and wholesalers earn $7.52 \%, 9.51 \%$ and $9.23 \%$ of profit Margin and these traders earn average revenue of 66,420 ETB, 129,360ETB and 280,343 ETB respectively. These low profit margins discourage the traders to engage in bamboo trading business. Bamboo furniture enterprises gained higher profit margin $(51.63 \%)$ than traditional bamboo processors $(7.62 \%)$.

Majority $(74.84 \%)$ of the total value added was appropriated as net profit for producers, traders and processors and the remaining $23.76 \%$ and $1.96 \%$ of the total value added was accounted for labour in the form of remuneration and government administration in the form of revenue as taxes and levies respectively. it indicates that the contribution of the bamboo sector to the government economy is limited. It indicates that the share of government administration from the total value added of bamboo products is limited. Therefore, an effort should be made to increase the contribution of the sector to the national economy. The trade and industry office should encourage the bamboo traders by giving its own license and other support services. The government and small scale and micro enterprises office should support 
both traditional bamboo product processors and furniture enterprises by providing working capital and working place and enhance the processors' skill and capacity to transform the business into more modern and profitable bamboo furniture enterprise.

\section{Abbreviations}

BoA: Bureau of Agriculture, BWADO: Banja Woreda Agricultural and Development Office, CSA: Central Statistical Agency

\section{Declarations}

\section{Consent for publication}

Not applicable

\section{Authors' contribution}

All authors read and approved the final manuscript

\section{Acknowledgements}

The authors would like to thank Debre Markos University, university of Gondar and ministry of education We also thank the sample respondents and experts of agricultural development office for their cooperation and support during data collection process.

\section{Competing interests}

The authors declare that they have no competing interests

\section{Funding}

The authors received no direct funding for this study

\section{Availability of data and materials}

The data used to support the finding of this study are available from the corresponding author upon reasonable request.

\section{Ethical approval and consent for participate}

Ethical clearance letters were collected Debre Markos University research and community directorate and Awi zone administrative office to care for the study participants and the researchers. During survey official letters were written for the district and each kebele informed verbal consent was obtained from each client, and confidentially was maintained by giving codes for each respondent. All participants 
throughout the research including households and enumerators were fully informed about the objectives of the study.

\section{References}

BoA (Bureau of Agriculture) .2012. Bamboo and jatrapha development and utilization in amhara region. regional bamboo and jatrapha work shop, may, 21-23, 2012, Bahir Dar, Ethiopia.

BWARDO (Banja Woreda Agricultural and Rural Development office) .2006. Plan of Banja woreda Agriculture and development office :Socio- economic characteristics of Banjia districts, pp2-3

CSA(Central Statistics Agency) .2007. Population Size by Sex, Area and Density by Region, Zone and Woreda. CSA, Addis Ababa, Ethiopia

Dafarzo ,A. S. 2016. Value chain and Rural livelihoods: Analysis of acacia mearnsii(black wattle) activities in njombe and lushoto districts msc thesis. Sokoine University Tanzania.P59

Embaye Kassahun .2003. Ecological aspects and resource management of bamboo forests in Ethiopia. Doctoral thesis Swedish university of agricultural sciences, Upasals, Swedish.

Lobovikov,M., Schoene D., andYping, L. 2011. Bamboo in climate change and rural livelihoods. Mitigation Adapt Strateg Global Change

Solomon ,Erifo., Lemma Zemedu and Teshale Wolde/amanuel. 2016. Value Chain Analysis of Bamboo Production: The Caseof Bule Woreda, Gedeo Zone.Jornal of industrial Engineering Letters,16(1),1-10 Vedeld ,P.,Angelesen ,A,Sjaastad ,Eand Berg ,G 2004. Counting on the environment: Forest income and the rural poor . Environmental economics series (Vol. 198). Wshington.

Zenebe Mekonnen., Adefires Worku., Temesgen Yohannes.,Mehari Alebachew., Demel Teketay and Habtemariam Kassa .2014. Bamboo Resources in Ethiopia: Their value chain and contribution to livelihoods. Ethno botany Research and Applications 12:511-524

\section{Figures}




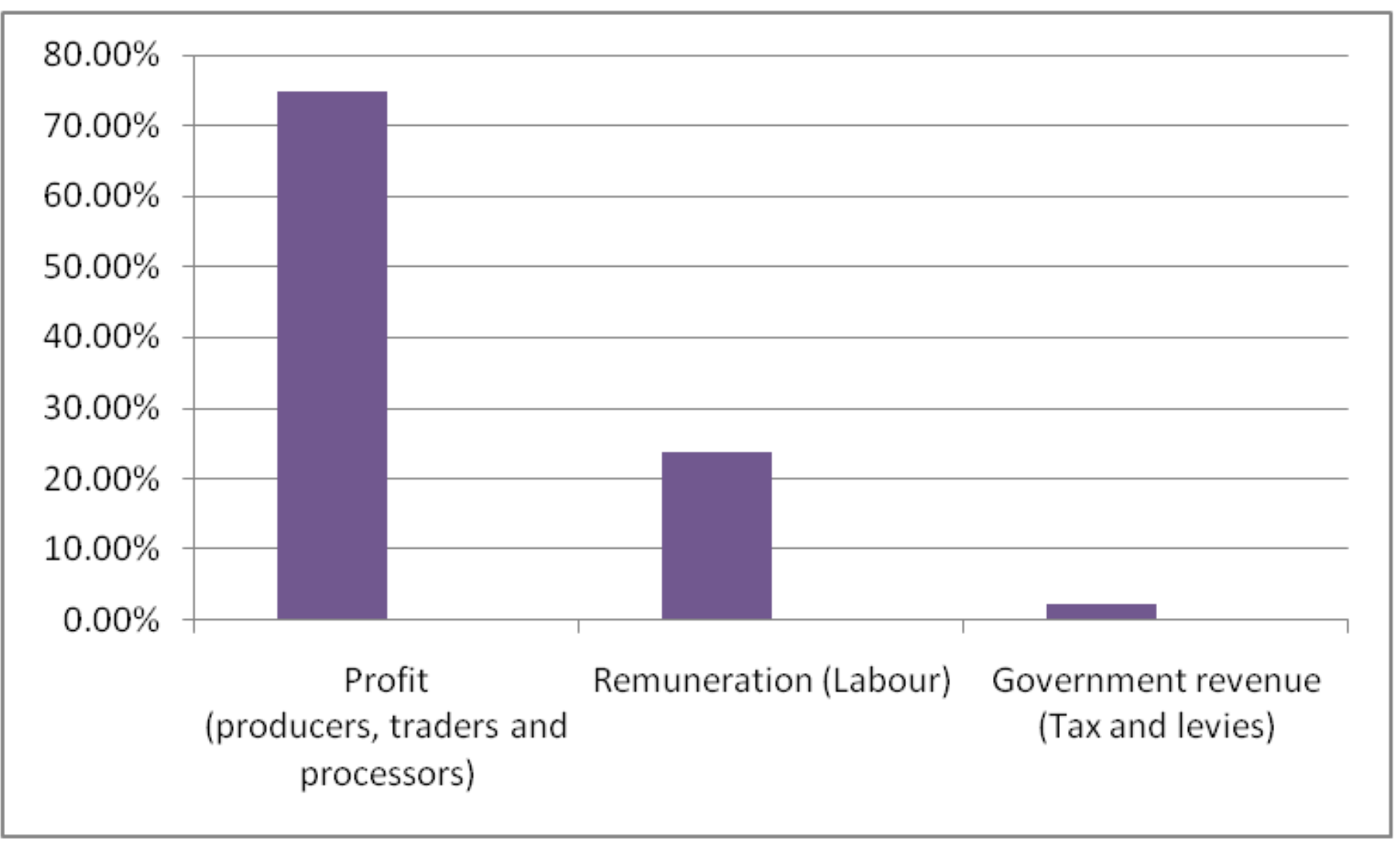

\section{Figure 1}

Value added distribution along different agents 


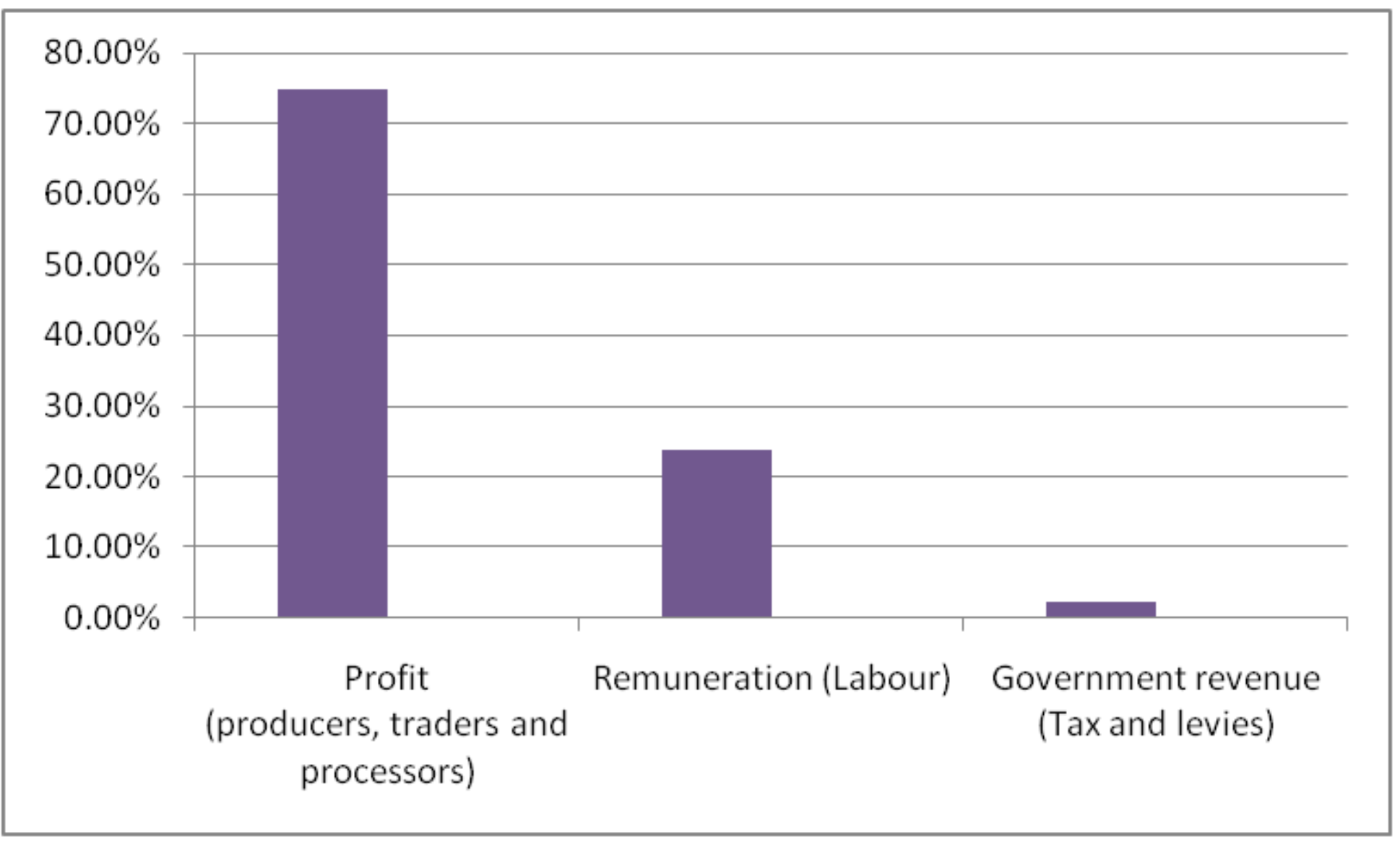

\section{Figure 1}

Value added distribution along different agents 